\title{
PENGOLAHAN DATA SEISMIK PADA DAERAH BATUAN VULKANIK
}

\author{
Raden Bagus Fauzan Irshadibima ${ }^{1)}$, Dwa Desa Warnana ${ }^{1)}$, dan Firman Syaifudin ${ }^{1)}$ \\ ${ }^{1}$ Teknik Geofisika, Fakultas Teknik Sipil dan Perencanaan, Instittut Teknologi Sepuluh Nopember \\ Email : Fauzan.irshadibima@gmail.com
}

\begin{abstract}
Abstrak. Eksplorasi sumber daya energi minyak dan gas sudah banyak dilakukan di berbagai macam lingkungan. Salah satunya reservoir minyak dan gas yang dapat terbentuk di lingkungan batuan beku (sub-vulkanik), dimana karena sifat alami batuan beku, gelombang yang menjalar melewati permukaan batuan tersebut akan terpantul atau mengurangi amplitudo seismik, sehingga data seismik yang terbaca akan mengalami banyak gangguan. Oleh sebab itu, perlu dilakukan penelitian yang berjudul "Pengolahan Data Seismik Pada Daerah Batuan Vulkanik" yang bertujuan untuk mengetahui tahapan pengolahan data seismik dan pengaruh dari hadirnya reflektor batuan beku terhadap hasil dari pengolahan data seismik. Tahapan yang digunakan dalam pengolahan dibagi menjadi tiga tahap utama yaitu Pre-Processing, Processing, dan Pre-Conditioning kemudian terakhir dilakukan migrasi menggunakan metode Post-Stack F-K Migration. Setelah dilakukan pengolahan data seismik, didapatkan penampang stacking seismik yang memperlihatkan event seismik pada rentang waktu $1000-3500$ ms dan hilang pada CDP 100-500 yang merupakan lapisan sub-vulkanik, sehingga pengaruh dari reflektor sub-vulkanik terhadap data seismik adalah memiliki kecepatan yang sangat besar daripada lingkungannya, gelombang frekuensi tinggi yang tidak dapat menembus lapisan tersebut, dan elevasi pada daerah lapisan sub-vulkanik yang tinggi. Sehingga Pengolahan data seismik konvensional yang digunakan belum dapat memperlihatkan event seismic tepat pada reflektor sub-vulkanik.
\end{abstract}

Kata Kunci: Batu vulkanik, Seismik, Pengolahan data

\begin{abstract}
Exploration of petroleum resources have been done in many type of environment. Petroleum system can be formed in igneous rock environment (subvolcanic), because of this rock properties, seismic wave that spread across this type of rock will be reflected or the amplitude will decrease, therefore obtained seismic data will encounter so many disturbance. Hence, it is necessary to research according to this topic with title "Seismic Data Processing in Volcanic Area" with objective to find out step for seismic processing and the impact for seismic processing with subvolcanic reflector present in the area. Step that used in this research is divide to three main phase, Pre-Processing, Processing, and Pre-Conditioning, last will be applied migration with Post Stack F-K Migration method. After processing have been done, the final result is seismic stack which show seismic event in 1000 - 3500 ms time and this event disappear in 100-500 CDP which appear to be subvolcanic reflector, and thus the impact of this reflector to seismic data is high velocity compared to surrounding area, high frequency wave that cannot penetrate this reflector, and high elevation at the top of subvolcanic reflector which affect the result of static correction. Hence, conventional seismic processing used cant show main seismic event on subvolcanic reflector.
\end{abstract}

Keywords: Subvolcanic, Seismic, Processing

\section{PENDAHULUAN}

Eksplorasi sumber daya energi yang bersumber dari minyak dan gas bumi di Pulau Jawa sudah banyak dilakukan dengan tantangan dan metoda yang beragam, seperti di Pulau Jawa yang ternyata beberapa batuan induknya tertutup lapisan batuan beku, contohnya seperti penelitian yang sudah dilakukan terdapat pada formasi Jatibarang, formasi yang tersusun oleh lapisan batuan beku (Boedi, 2010).

Batuan beku yang menutupi batuan induk akan menyebabkan penjalaran gelombang seismik terganggu, efek ini terjadi karena sifat alami dari batuan beku yaitu memiliki sifat refraksi yang kuat (Huijun dan Pal, 2009). Efek ini akan mempengaruhi data seismik karena pada saat melewati lapisan batuan beku penjalaran gelombang seismik terdapat energi yang hilang (amplitudo berkurang), dan dari hasil penelitian-penelitian yang sebelumnya mengakibatkan hasil pengolahan data dari penampang seismik buram/tidak jelas (Hill et al., 2016).

Penelitian ini dilakukan dengan memfokuskan pengolahan data seismik di bagian lapisan batuan vulkanik, dengan menerapkan metode-metode quality control (QC), yaitu membandingkan hasil 
pengolahan dengan nilai parameter yang berbedabedadan koreksi statik yang diaplikasikan pada data seismik daerah batuan vulkanik.

\section{TINJAUAN PUSTAKA}

\section{Batuan Beku Vulkanik}

Batuan beku terbentuk karena proses pengerasan dari magma yang merupakan campuran dari air, gas yang terlebur (dissolved gas) dan lelehan yang sebagian besar merupakan lelehan batuan. Batuan beku memiliki berbagai macam ragam kandungan mineral nya tergantung dari kandungan magma tempat dia terbentuk, yang bervariasi diantara silicon, besi, magnesium, sodium, kalsium dan potasium. Batuan beku juga mempunyai struktur yang beraneka macam yang mempengaruhi properti fisiknya seperti porositas dan permeabilitas tergantung bagaimana dia ditempatkan saat pembentukkannya (Huijun dan Pal, 2009).

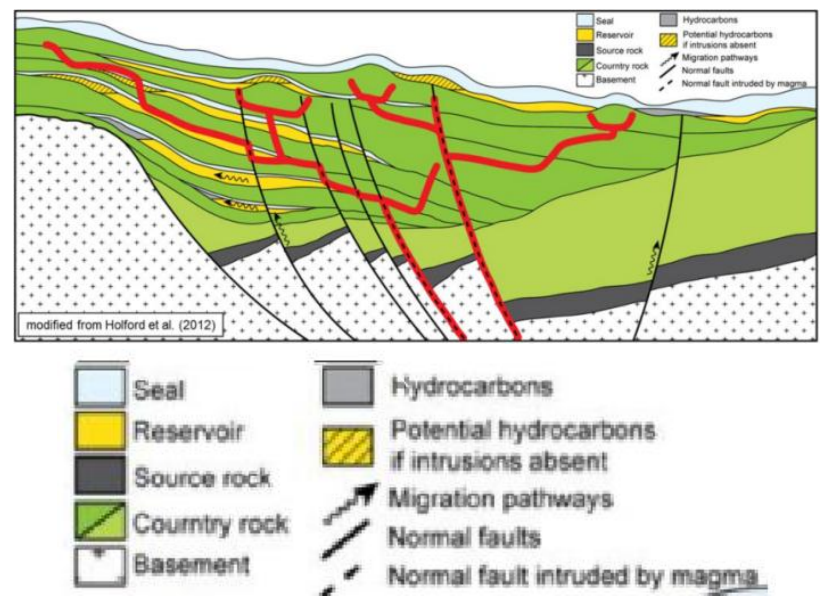

Gambar 1Petroleum System daerah batuan vulkanik

(Holford et al., 2012)

Model geologi daripada sistem petroleumyang berada di lingkungan batuan vulkanik memiliki unsur-unsur yang mirip dengan sistem petroleumpada umumnya. Pada keadaan ini, batuan vulkanik mengintrusi daerah reservoir. Intrusi ini membentuk barrier di sekitar zona reservoir yang mengarah baik vertikal maupun horizontal.

\section{Pengolahan Data Seismik}

Pengolahan data seismik bertujuan untuk mengubah data seismik dari hasil recording di lapangan menjadi suatu penampang seismik (stack) yang kemudian dilakukan interpretasi dari penampang tersebut. Sedangkan tujuan pengolahan data seismik adalah untuk menghasilkan penampang seismik dengan kualitas signal to noise ratio (S/N) yang baik tanpa mengubah bentuk kenampakan-kenampakan refleksi/pelapisan batuan bawah permukaan, sehingga dapat dilakukan interpretasi keadaan dan bentuk dari struktur pelapisan bawah permukaan bumi seperti kenyataannya (Yilmaz, 2001). Atau dapat dikatakan bahwa pengolahan data seismik didefinisikan sebagai suatu tahapan untuk meredam noise dan memperkuat sinyal.

\section{Spherical Divergence}

Sewaktu gelombang akustik dipancarkan oleh sumber seismik yang menjalar ke bawah permukaan, energinya akan tersebar dengan arah seperti bola. Semua energi yang tersimpan dalam sumber seimik akan terpencar ke area yang semakin luas dengan bertambahnya waktu. Efek ini akan menyebabkan energi yang hilang dari sinyal seismik dan mengakibatkan pengurangan amplitudo dari wavelet sumber, inilah yang disebut dengan efek spherical divergence.

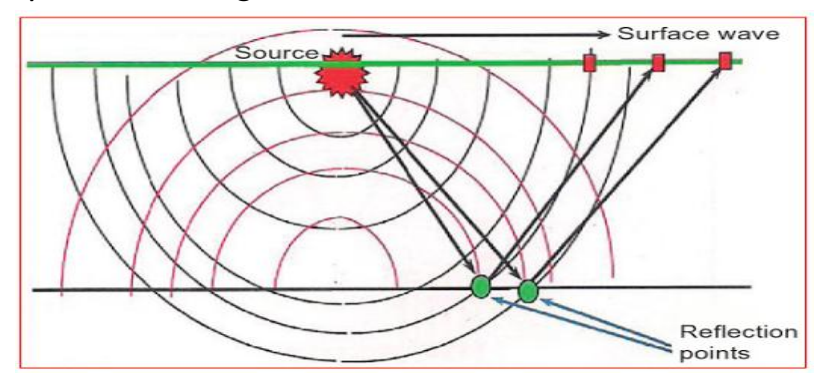

Gambar 2Konsep Spherical Divergence (Onajite, E. 2014)

Pengembalian energi ini dapat diselesaikan dengan menggunakan formula P.Newman seperti dibawah.

$$
D=T \frac{\mathrm{V}_{\mathrm{RMS}}^{2}(T)}{V_{0}}
$$

dimana :

$D=$ Power

$T=$ Time

Vrms $(T)=$ Kecepatan Root Mean Square

$V_{o}=$ Konstanta Kecepatan

Pengolahan True Amplitude adalah salah satu langkah yang digunakan untuk mengkompensasi atenuasi, spherical divergence dan efek lainnya 
dengan menyesuaikan amplitudo pada data. Tujuannya adalah untuk menghasilkan data pada keadaan dimana amplitudo refleksi berhubungan langsung dengan perubahan properti batuan seperti yang sesungguhnya (Onajite, 2014).

\section{Dekonvolusi}

Dekonvolusi adalah suatu proses untuk menghilangkan pengaruh dari wavelet sumber dari suatu trace seismik. Dengan proses tersebut diperoleh deret pseudo refleksi yang berupa spike yang menggambarkan amplitudonya.

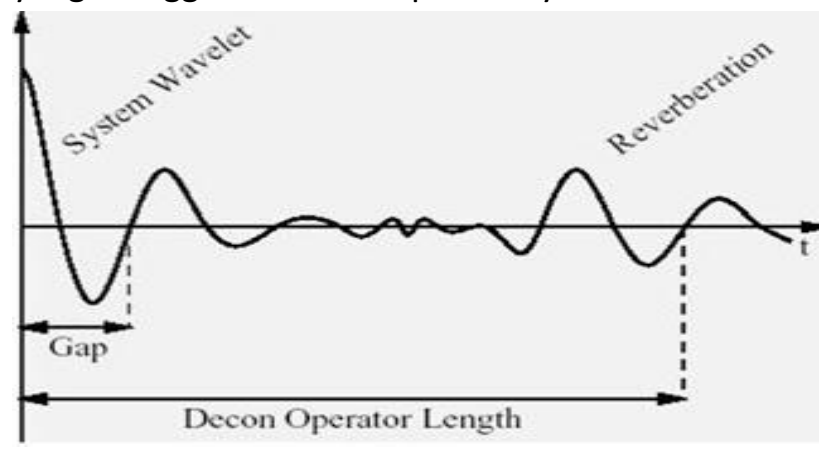

Gambar 3/lustrasi Operator Length dan Gap

Persamaan Dekonvolusi berasal dari konvolusi yang diperlihatkan oleh persamaan dibawah.

$S(t)=W(t) * R(t)$

dengan :

$S(t)=$ sinyal

$W(t)=$ wavelet

$R(t)=$ koefisien refleksi.

Sehingga dekonvolusi adalah :

$R(t)=W(t)^{-1} * S(t)$

Dekonvolusi merupakan tahapan untuk melakukan koreksi terhadap efek filter bumi tersebut sehingga diperoleh hasil dimana wavelet yang terekam dapat dikembalikan menjadi tajam dan dengan amplitudo yang tinggi.

\section{Filter F-K}

Noise multiple perioda panjang bisa dihilangkan dengan berbagai metode seperti filter F$\mathrm{K}$, Karhunen-Loeve (KL) transform dan Transformasi Radon (Saputra dan Deni, 2006). Metode atenuasi noise dapat digunakan dengan filter $\mathrm{F}-\mathrm{K}$, yang merupakan domain frekuensi dan domain bilangan gelombang. Karena noise yang terekam juga memiliki frekuensi tertentu, maka dengan mengaplikasikan filter F-K dapat dipilih (picking) frekuensi yang diharapkan sesuai dengan sinyal reflektor.

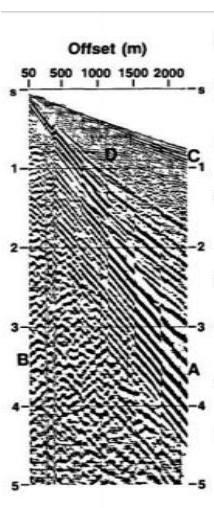

(a)

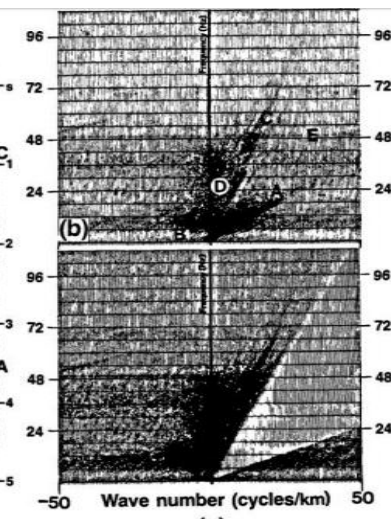

(c)

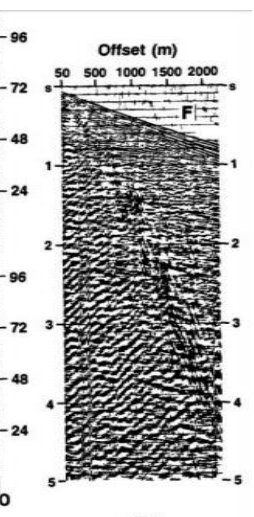

(d)
Gambar 4Filtering data seismik dengan menggunakan F-K (Yilmaz, 2001)

Filter F-K juga dapat meresolusi struktur dengan kemiringan yang curam, dan dapat diperlakukan juga pada data dengan rasio signal to noise yang rendah atau dengan kata lain data yang buruk. (Yilmaz, 2001).

\section{Migrasi Seismik}

Migrasi data seismik adalah suatu proses untuk memetakan suatu penampang menjadi penampang yang lain dimana event-event seismik dikembalikan posisinya pada tempat/lokasi dan waktu yang tepat (pada domain time ataupun domain depth).

Proses migrasi difraksi sering juga dianalogikan sebagai pendekatan statistik. Dalam metoda ini datum yang akan diperoleh, akan mempunyai banyak kemungkinan. Keuntungan utama dari migrasi difraksi ini adalah penampilan kemiringan curam yang baik, sedangkan salah satu kerugiannya adalah kenampakan yang buruk jika data seismik mempunyai rasio $\mathrm{S} / \mathrm{N}$ yang rendah. 


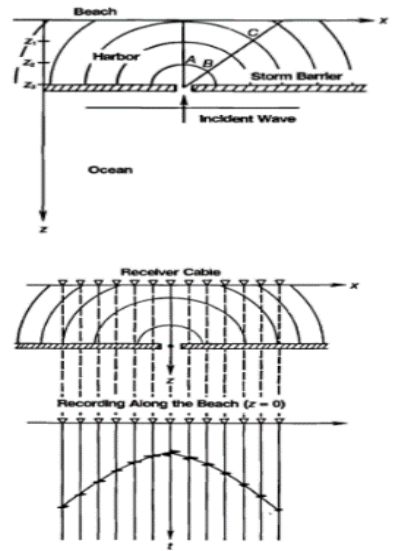

Gambar 5llustrasi konsep dalam migrasi Kirchhoff (Yilmaz, 1987)

\section{METODOLOGI PENELITIAN}

Pada tahap pengolahan data, terdapat tiga langkah yang akan ditempuh, yaitu Pre-Processing bertujuan sebagai quality control data tahap awal yaitu menerapkan geometri yang didapat di lapangan kedalam data dan static data correction, kemudian dilakukan muting gather yang bertujuan untuk mematikan gather yang dianggap bukan data.

Lalu masuk ke tahap Processing pada tahap ini ditentukan nilai parameter dari tiap langkah yaitu Frequency Filter yang menggunakan Ormsby Filter, Spherical Divergence, Deconvolution, dan terakhir adalah $F-K$ Filter.Setiap melalui tahapan pada Processing dilakukan stacking untuk QC (Quality Control) hasil tiap parameter.

Kemudian Pre-Conditioning yang bertujuan untuk melakukan $Q C$ terakhir dengan analisa kecepatan dan jika dihasilkan penampang seismik yang belum mengenai target reservoir maka dilakukan Static Data Correction yang kedua. Yang terakhir adalah tahap migrasi, migrasi dilakukan dengan menggunakan metode F-K Post-Stack Time Migration.

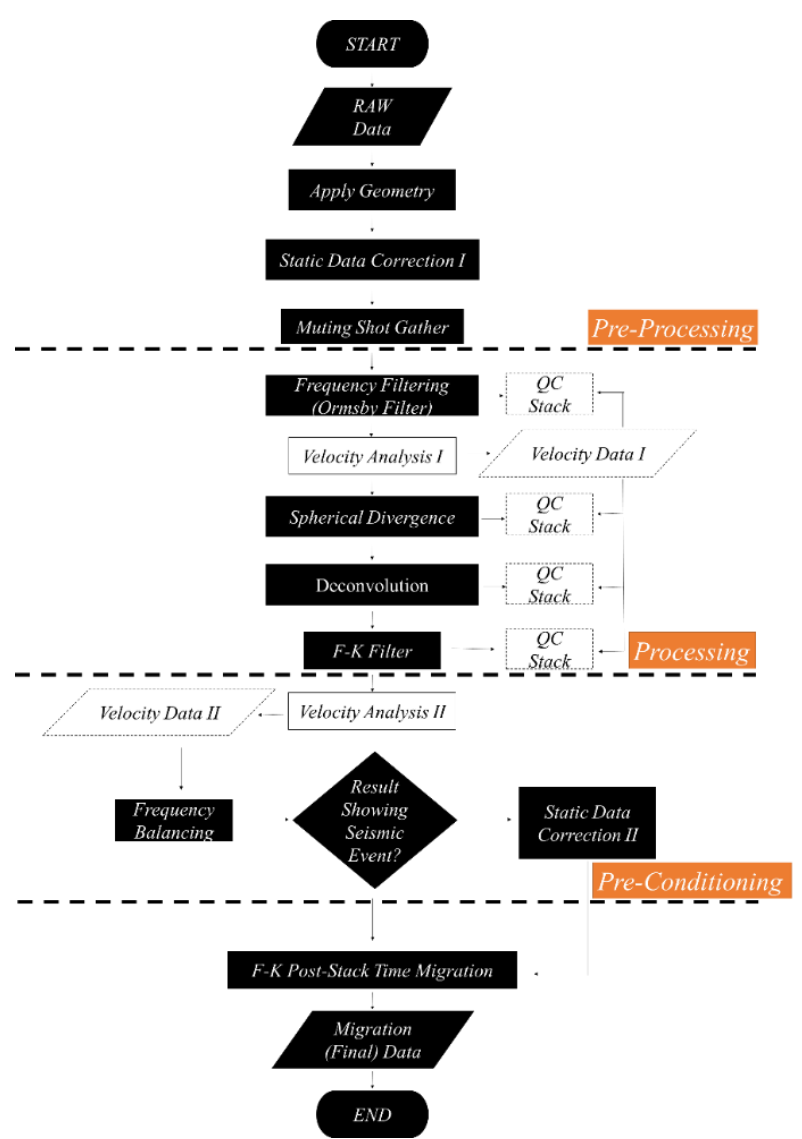

Gambar 6Diagram Alur Pengolahan Data

\section{HASIL DAN PEMBAHASAN}

\section{Hasil Pengolahan}

Input data pada tahap ini masih dalam bentuk RAW Gather yang masih memiliki banyak noise yang harus dikurangi untuk mendapatkan hasil seismik yang baik. Setelah dilakukan input data yang selanjutnya dilakukan adalah memasukkan geometri, yang berupa informasi yang didapatkan dari pengukuran dilapangan. Geometri terkait dengan lokasi data shot dan receiver (dalam koordinat), kedalaman uphole dan downhole dan lain-lain.

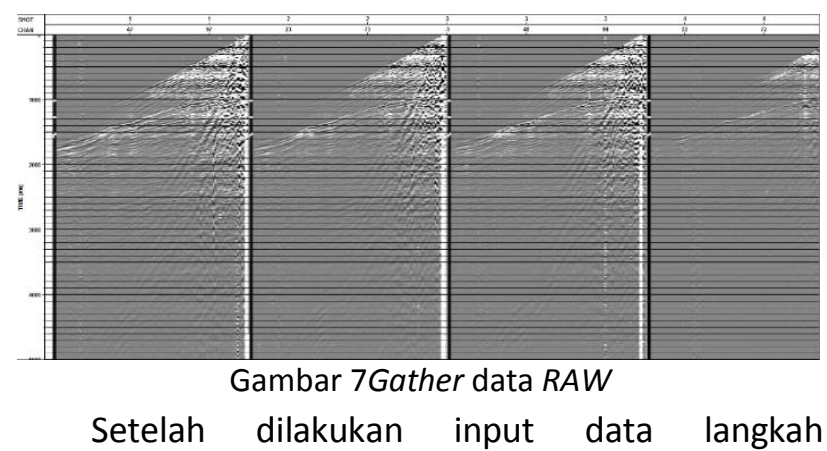

selanjutnya adalah static correction dimana tahapan ini bertujuan untuk mengembalikan offset saat survei dilapangan, sehingga membentuk topografi 
yang sesuai dengan keadaan lapangan, langkah yang dilakukan pertama adalah melakukkan picking first break.

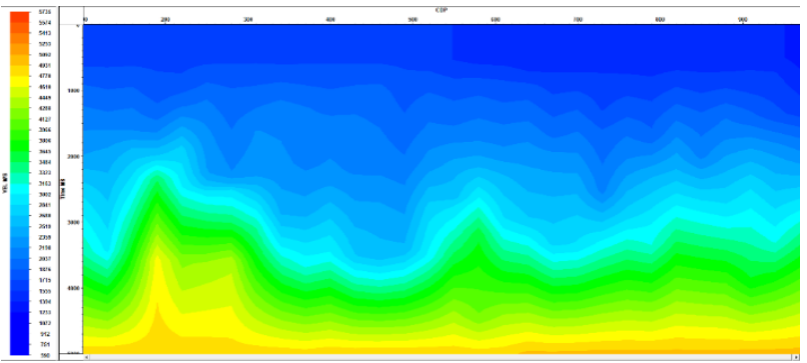

Gambar 8 Model Statik

Seperti yang ditampilkan pada gambar diatas, pengambilan first break untuk kecepatan lapisan pertama dan kedua sudah dilakukan dan sudah menyerupai elevasinya, pada model statik diatas terdapat daerah dengan kecepatan yang tinggi (berwarna merah).

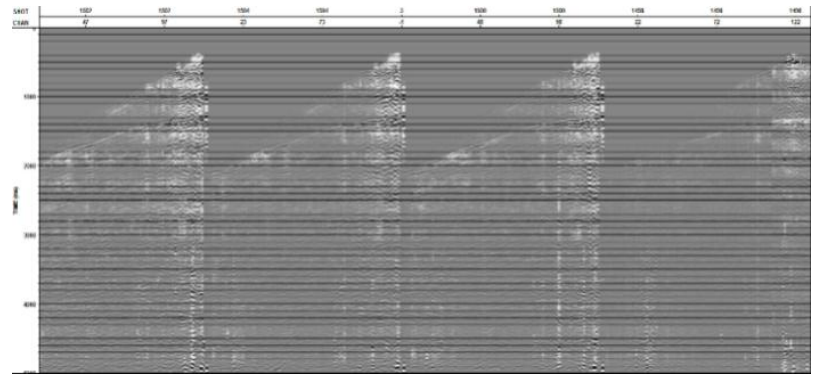

Gambar 9Gather RAW setelah Statik

Proses Filter Frekuensi adalah proses pengurangan noise yang ada pada data seismik yang memiliki frekuensi rendah dan tinggi dengan menggunakan Bandpass Filter tipe Butterworth. Digunakan parameter $5 \mathrm{~Hz}-10 \mathrm{~Hz}-55 \mathrm{~Hz}-60 \mathrm{~Hz}$.

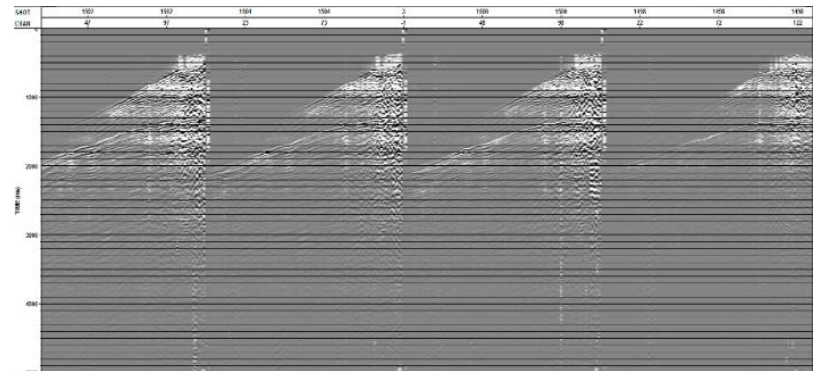

Gambar 10Gather Setelah Filter Frekuensi

Setelah proses filter frekuensi untuk dapat melanjutkan proses pengolahan data seismik dilakukan analisa kecepatan, dimana pada tahap ini kecepatan untuk tiap-tiap time (dalam ms) di definisikan. Pada saat menganalisa kecepatan, muting data pada gather CDP (Common Dip Point) akan sangat membantu karena dapat menghilangkan first break yang tidak diambil informasinya dalam pengolahan data seismik.

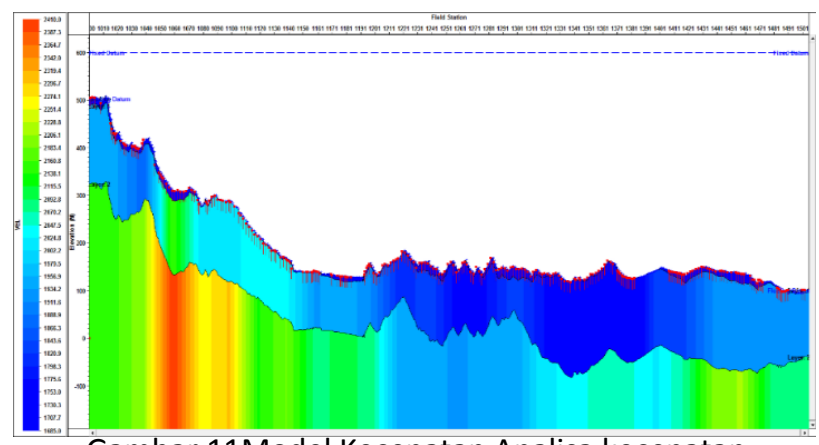

Gambar 11Model Kecepatan Analisa kecepatan

Kemudian dilakukan koreksi spherical divergence yang berfungsi untuk mengembalikkan energy/ amplitudo yang hilang karena pengaruh jarak (geometri), difraksi pada lapisan dan absorpsi yang terjadi pada batuan. Parameter yang digunakan adalah $\mathrm{T}: \mathrm{V}=2: 1$.

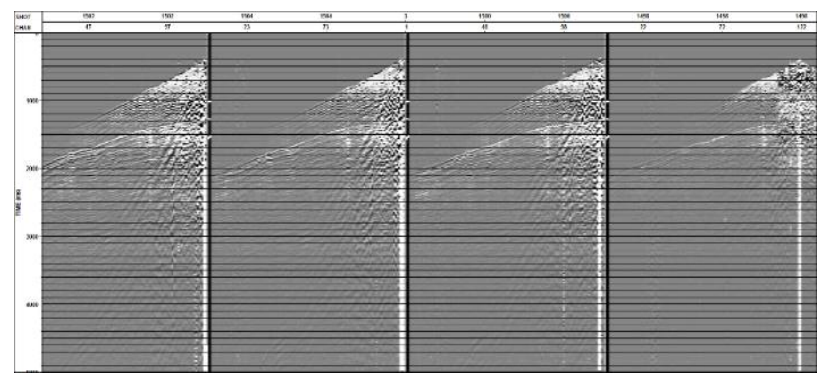

Gambar 12Gather spherical divergence

Tahap selanjutnya adalah deconvolution, tahap ini menggunakan prinsip inversi dimana pengaruh dari pengurangan kualitas data karena adanya reverberasi dan efek dari lapisan yang cukup kompleks sehingga pada data ini diperlukan perbaikan resolusi vertical, sehingga untuk mengatasi masalah tersebut perlu dilakukan dekonvolusi. Parameter yang digunakan sehingga menghasilkan autocorelation 2 Operator Length 150 Lag 60.

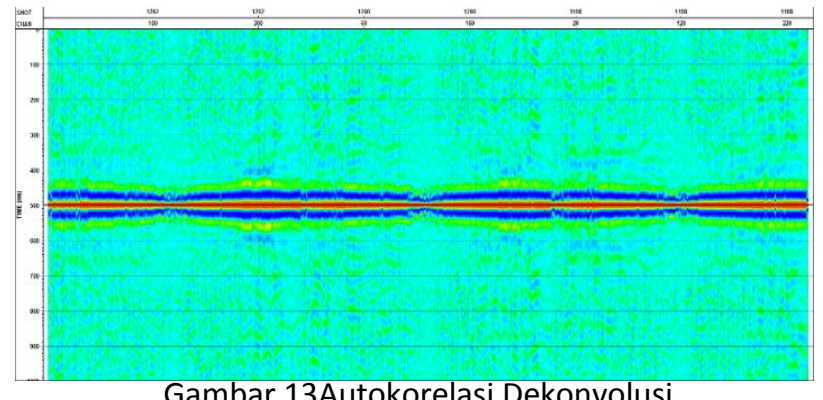

Setelah dilakukan proses Dekonvolusi sehingga data mempunyai resolusi yang baik, langkah selanjutnya adalah melakukan filter untuk 
menghilangkan noise yang masih tersisa, yaitu noise ground roll, linear noise, dan noise-noise frekuensi lainnya. Pada tahap filter F-K, langkah pertama adalah menentukkan zona muting, pada F-K spectrum analysis. Muting ini bertujuan untuk meningkatkan kualitas data dengan menyeleksi frekuensi data, agar noise ground roll yang mempunyai kecepatan frekuensi yang berbeda dengan data dapat terseleksi dan kemudian dipotong dengan menggunakan mute.

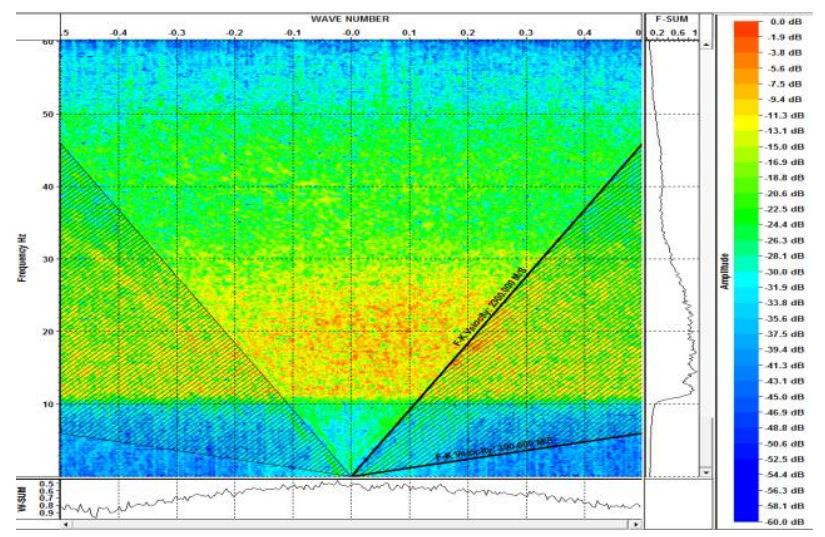

Gambar 14 Desain Mute Filter F-K

Seperti yang terlihat pada gambar di atas, penggunaan mute dilakukan oleh daerah yang menyimpang pada batas frekuensinya, yang kemudian diolah dengan menggunakan filter F-K dan menghasilkan data dengan noise ground roll, noise linear yang lebih sedikit.

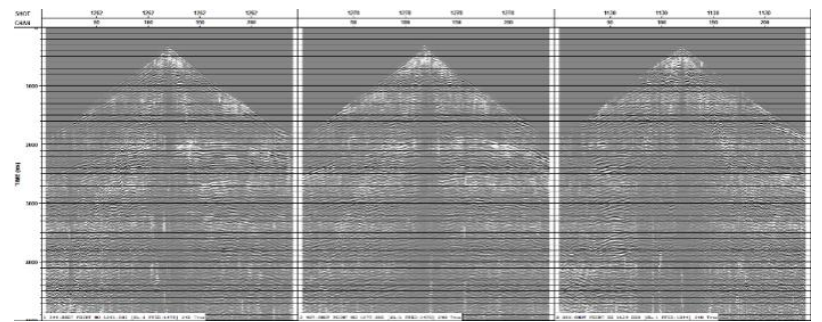

Gambar 15 (a) Gaher sesudah dilakukan filter F-K

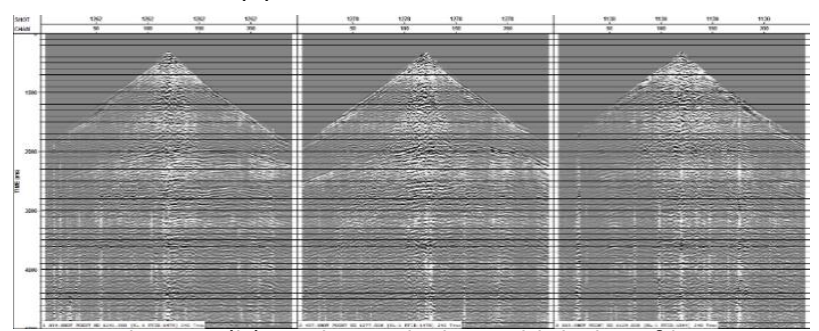

Gambar 15 (b) Gather sebelum dilakukan filter F-K

Kemudian dilakukan tahapan selanjutnya yaitu persiapan sebelum dilakukan migrasi, frekuensi balancingdilakukan untuk menaikkan/ menyeimbangkan data terhadap frekuensi, pada penelitian ini frekuensi yang di naikkan adalah frekuensi rendah, sehingga menghasilkan penampang yang merupakan reflektor dari hasil gelombang frekuensi rendah. Tahap selanjutnya adalah residual statik dimana tahap ini bertujuan untuk mengkoreksi kembali hasil statik setelah data sudah dilakukan pengolahan sehingga error yang didapat lebih kecil.

Setelah tiga tahap utama sudah dilakukan selanjutnya adalah melakukan migrasi, yaitu mengembalikkan reflektor seismik keposisi semula. Metode yang digunakan adalah metode Post stack F-K migration, karena termasuk salah satu migrasi yang cukup cepat dan akurat prosesnya.

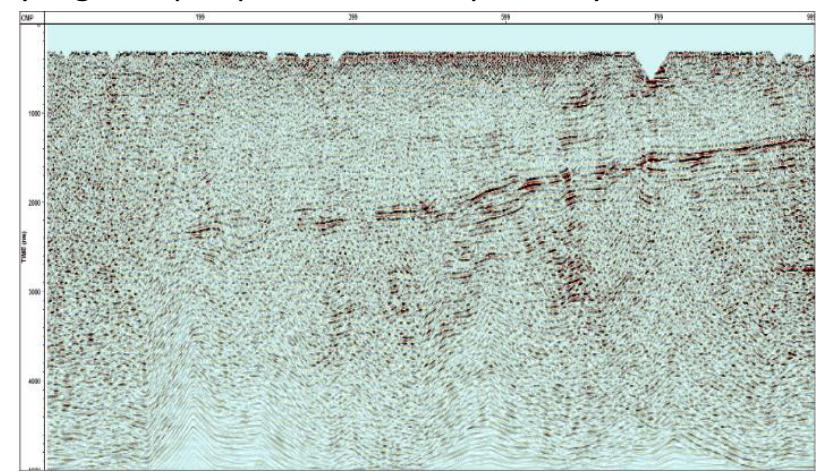

Gambar 16 Stack sesudah dilakukan Post stack F-K migration

Setelah dilakukan migrasi terlihat reflektor seismic yang dikembalikkan ke posisi sesungguhnya, pengaruhnya dapat mempertebal reflector tersebut. Dengan dilakukannya migrasi maka data seismik yang ditampilkan memperlihatkan bentukkan event yang sebenarnya seperti dilapangan.

Dimana sebelumnya telah dilakukan pengolahan untuk menghilangkan noise pada data, baik noise multpel, linear, frekuensi rendah dan tinggi pada tahap processing. Juga dilakukan enchantment data menggunakan metode frequency balancing dan residual statik yang dapat meningkatkan resolusi lapisan reflektor.

Reflektor sub-vulkanik yang menjadi fokus penelitian belum dapat dimunculkan, hal ini dikarenakan frekuensi gelombang yang melewati reflektor langsung dipantulkan kembali, walaupun terdapat frekuensi rendah yang dapat melewati reflektor ini namun metode pengolahan konvensional yang digunakan belum dapat 
memunculkan gelombang yang termasuk kedalam frekuensi rendah.

Faktor kedua adalah metode pengolahan data seismik konvensional yang menganggap bahwa sifat setiap lapisan adalah isotropis, sedangkan pada kenyataannya setiap lapisan khususnya lapisan subvulkanik berbeda sifat nya (kecepatannya) dengan sekitarnya, sehingga menyebabkan analisa kecepatan memiliki eror yang cukup tinggi.

Faktor ketiga adalah statik, statik pada data seismik akan menjadi sangat penting, karena elevasi pada data sekitar zona subvulkanik (CDP 100 - 500) tinggi, sehingga dibutuhkan metode statik yang lebih advance dibandingkan dengan mengandalkan statik first break dan residual statik, yaitu salah satu metodanya adalah statik menggunakan tomografi, dimana metode ini memanfaatkan model ray-trace yang sesuai dengan informasi elevasi dan posisi shot maupun receiver sehingga hasil dari statik menjadi lebih akurat dan akan memperlihatkan event seismik.

Faktor keempat adalah metode akuisisi yang konvensional, dimana apabila menggunakan metode konvensional maka reflektor sub-vulkanik yang hadir dalam lingkungan akuisisi akan selalu memantulkan gelombang seismik yang ditembakkan.

\section{PENUTUP}

\section{Kesimpulan}

Kesimpulan yang didapat dari penelitian ini antara lain.

1. Tahapan pengolahan data adalah preprocessing yang dilakukan dengan tujuan menginput data seismik dan menginput informasi geometrinya, kemudian tahapan processing yang bertujuan untuk menghilangkan noise pada data seismik, kemudian dilakukan pre-conditioning yang dilakukan untuk meningkatkan ketajaman dari event seismik dan terakhir migrasi yang berfungsi untuk mengembalikkan posisi reflektor ke posisi yang sesungguhnya.

2. Hasil pengolahan data memperlihatkan event seismik yang terletak pada rentang waktu 1000
- 3500 ms dan hilang pada CDP 100-500 yang merupakan reflektor sub-vulkanik

3. Pengaruh lapisan reflektor sub-vulkanik terhadap data seismik adalah memiliki kecepatan yang sangat besar daripada lingkungannya, gelombang frekuensi tinggi yang tidak dapat menembus lapisan tersebut, dan elevasi pada daerah lapisan sub-vulkanik yang tinggi sehingga sangat mengurangi kualitas dari hasil yang didapat setelah pengolahan data dilakukan. Pengolahan data seismik konvensional yang digunakan untuk lingkungan sub-vulkanik belum dapat memperlihatkan event seismic.

\section{Saran}

Saran yang dapat diberikan berdasarkan hasil dan kesimpulan untuk membangun hipotesahipotesa selanjutnya antara lain.

1. Untuk mendapatkan hasil yang lebih baik dan akurat, perlu dilakukan analisa kecepatan dengan perlapisan kecepatan anisotropis di lingkungan sub-vulkanik.

2. Perlu dilakukan metode koreksi statik yang lebih akurat, contohnya menggunakan metode koreksi statik tomografi.

3. Akuisisi pada lingkungan sub-vulkanik harus dilakukan berbeda dengan lingkungan yang konvensional, karena reflektor yang selalu memantulkan gelombang tepat dibawah posisi penembakkan gelombang, sehinga perlu dilakukan akuisisi seperti far-offset sehingga penembakkan gelombang tidak langsung dari atas reflektor sub-vulkanik dan dapat mencapai target yaitu dibawah reflektor tersebut.

\section{Ucapan Terima Kasih}

Penulis mengucapkan terima kasih kepada dosen- dosen pembimbingBapak Dwa Desa Warnana dan Bapak Firman Syaifuddin atas ide penulisan dan pengarahannya selama proses penelitian hingga penulisan. 


\section{DAFTAR PUSTAKA}

Boedi, W., 2010, Optimisasi produksi lapangan Minyak "Mature" Struktur " $X$ " Lapangan " $Y$ " PT. PERTAMINA EP Region Jawa, Teknik Geologi UPN "Veteran" Yogyakarta.

Hill, D., L. Combee, and J. Bacon, 2006, Over/Under Acquisition and Data Processing: The Next Quantum Leap in Seismic Technology?, First Break 24, no 6.

Holford, S.P., N. Schofield, J.D. Macdonald, I.R. Duddy, and P.F. Green, 2012, Seismic Analysis of Igneous Systems in Sedimentary Basins and Their Impacts on Hydrocarbon Prospectivity: examples from the southern Australian margin: The APPEA Journal, v. 52, p. 52.

Huijun, H., dan A. Pal, 2009, Evaluating Volcanic Reservoirs. Oilfield Review Spring, Schlumberger.

Onajite, E. 2014, Seismic Data Analysis Techniques in Hydrocarbon Exploration. Elsevier's Science \& Technology Rights Department, Oxford, UK.

Saputra dan Deni. 2006, Atenuasi Multipel pada Data Seismik Laut dengan Menggunakan Metoda Predictive Deconvolution dan Radon Velocity Filter.

Yilmaz, Ö., 1987, Seismic DataProcessing, Society of Exploration Geophysics.

Yilmaz, Ö., 2001, Seismic Data Analysis, Processing, Inversion, and Interpretation of Seismic Dat, Volume I, Society of Exploration Geophysicists: Tulsa USA. 